\title{
Japanese and South Korean Approaches to Overcoming Gender Inequality: A Comparative Analysis
}

\author{
Andreeva Anastasiia
}

\begin{abstract}
Despite common historical background and similarities in cultural values, movement for gender equality is occurring differently in Japan and The Republic of Korea: it is being treated as a side effect of Abe's womenomics in the first case and has a solid base of social initiative that fills in the gaps of the governmental policy in the second one. The paper suggests that aside from the civil activity level, there is another key reason for the difference in approaches which is the attitude to the "comfort women" problem.
\end{abstract}

Keywords - comfort women, gender hierarchy, social movement, womenomics.

\section{INTRODUCTION}

Despite being labelled as developed societies, for which gender equality is named a necessity, Japan and The Republic of Korea rank low $\left(110^{\text {th }}\right.$ and $115^{\text {th }}$, respectively) in 2018 The Global Gender Gap Index by World Economic Forum [1].

However, there are positive dynamics, and the reason for that is a movement for gender equality, which exists in both countries, but has different impulses and methods of realization. In Korea, a grass-roots social initiative serves as an impulse for gender equality movement whereas in Japan the movement is mostly stimulated by Prime Minister Shinzo Abe's government within the framework of the womenomics policy.

Japan and The Republic of Korea are neighboring countries sharing common historic background and a long history of mutual influence. Given these factors, it was not illogical to assume that social transformations of the XXI century would also occur in a similar way. However, the reality provides no such evidence, and we intend to determine why.

The aim of the study is to investigate the difference in Japanese and South Korean mechanisms for achieving gender equality. Following research objectives would facilitate the achievement of the aim: examining historical and cultural background of the issue in both countries; determining the starting point of the discrepancy between Japanese and South Korean approaches to gender policy in their shared history; establishing matters of foreign and domestic policy which triggered the abovementioned discrepancy; describing, analyzing and comparing current mechanisms of power structure reshaping and gender hierarchy revision in Japan and The Republic of Korea; investigating involvement in the

Anastasiia Andreeva is with the National Research University Higher School of Economics, Russian Federation. processes of the government and society.

The study is based on qualitative content analysis. The texts materials were taken from primary sources such as mass media (to obtain information on recent situation) as well as from secondary sources (to investigate the current state of knowledge and researchers' approaches to the topic). The data from national surveys and statistic bases were also incorporated to reinforce theoretical conceptions. In order to achieve a complex comprehension of the issue, we critically analyzed texts by Japanese and South Korean authors, written in Japanese and Korean, as well as by international scholars. Performing cross national comparative research, we used culture-free and culture-bound approaches as complimentary tools, which allowed us to get both highly specific conclusions within the context frame and universal ones with a high degree of abstraction.

\section{COMMON BACKGROUND AND THE STARTING POINT OF THE DISCREPANCY}

Having been included into sinosphere for the most part of their history, both Japan and Korea incorporated various elements of Chinese culture into their own ones. Confucian principles in particular formed the basis for social order. Confucianism introduces a rigid hierarchy for all areas of life and makes a strict distinction between male and female gender roles. According to Confucian postulates, men and women are inherently unequal for the reason of masculine principle being the embodiment of positive creative energy and feminine principle, on the contrary, being the one of negative passive energy. Consequently, public sphere has become a domain of male authority while women have been locked in private sphere. Confucianism enforces a system of three obediences (三従 sanjyū in Japanese) which implies obedience to the father before marriage, obedience to the husband during marriage, and obedience to the son in old age, thus establishing women's subordinate status in the society. Religion (Buddhism in both countries, Christianity in Korea) has contributed to unequal distribution of power, justifying it by primordial moral superiority of men. Geographical isolation of Japan and Korea has led to ethic and cultural homogeneity, thereby further exacerbating strict hierarchy of the societies.

Japanese and South Korean historical paths of development are also closely connected. There was a period of self-imposed national isolation in both Japanese and Korean history, but Japan managed to conduct a large-scale modernization in the face of the rising threat from the West and Korea did not. 
Consequently, it became Japan's colony and was remaining under political, economic and cultural domination of Japan since 1910 to 1945 . Having started the Second World War as a metropole and a colony, after the end of it Japan and Korea appeared to be in a similar condition. Japan and the Republic of Korea also chose the same tactic for overcoming post-war devastation and soon earned themselves a name of developed countries.

For the first time in the history of Japan and the Republic of Korea gender equality was institutionalized in the national constitutions adopted following the Second World War under American influence. However, formal implementation of Western liberal democracy did not mark the end for Confucian norms being regulators of the society. The driving force for the economic miracle was collectivist allegiance to the state. For men, it translated into lifelong work for a firm to boost national economy (for the Republic of Korea, given the constant threat of an armed conflict with Democratic People's Republic of Korea, military service was also of great importance). For women, it took the form of unpaid domestic work (the key point being upbringing of children) so that their husbands and fathers could dedicate themselves fully to their duties towards the state.

Women's lives were centered around family to an extent where they could not exist outside of male-dominated household, which was guaranteed by a paternalist family registers system. Family registers, known as koseki (戸籍) in Japan and hojeok (호적) in Korea were introduced in 1872 and 1909, respectively, to control the population dynamics. Hojeok were abolished in 2007 by decision of the Constitutional Court for the reason of hoju system (호주, male head of the family system) violating the right to gender equality [2]. Koseki remains the legal basis of Japanese society structure. Such document contains information about names, births, marriages, adoptions, deaths of all the members of a nuclear family. Each family-household must have a head, as a general rule, a male one. According to the Ministry of Internal Affairs and Communications of Japan, the household head status is transmitted from a father to the first son, then to the second son, and the only way for a woman to become a head is to generate income while her husband does not have one [3]. Given that family name and address of a head become the ones for all the members of a household and a head retains the legal title even after death, a woman is always somebody's daughter, wife or widow and never a person of her own.

To conclude, in Japan and the Republic of Korea developed economy is combined with anachronistic patriarchal public institutions. These societies were characterized by rigid hierarchy based on gender inequality, strict distinction between male and female gender roles, and established male dominance in public sphere. As for women, their social status was always determined by relation to a man, social set was reduced to a one of daughter, mother, wife or widow.

\section{THE NINETIES: TIMES OF GREAT CHANGES}

Confucian dogmas, having been an engine of immense economic growth after the Second World War, started retarding further development in the 1990s. The reason for that is the Asian economic crisis of 1997, which triggered processes that reshape the current power structure and gender hierarchy in Japanese and South Korean societies. Financial capacity of a man was no longer sustainable enough to provide proper support to a non-working wife and child, which led to increasing entry into the labor market of women, erosion of the traditional family, redefinition of masculinity and femininity concepts, and overall progress towards gender equality. The nineties were also the time when Japan and Korea joined the international trend on promoting gender equality: Japan's Basic Law for a Gender Equal Society and South Korea's Women's Development Act were implemented in 1999 and 1995, respectively. For the Republic of Korea, there was another major event that created an environment for the abovementioned progress. Transition in 1987 to the Sixth Republic, which was more liberal and democratic than the authoritarian Fifth Republic, improved a political climate in the country. By virtue of this political turn, the problem of "comfort women" was finally brought to light, when Yun Chung-Ok presented her research on the issue at a conference organized by the Korean Church Women United on sex tourism in 1988 [4]. The fact that the 1990s became a major turning point in terms of gender equality for both Japan and Korea can be demonstrated by the figures of the Gender Inequality Index: the index value dropped from 0.156 in 1995 to 0.103 in 2017 for Japan and from 0.277 to 0.063 for the Republic of Korea [5].

The most essential consequence of the economic crisis was erosion of the traditional family. In the new realities women no longer could live relying solely on a husband's financial capacity so they were more likely to pursue a long-term career and less likely to get married and have children. The newfound financial autonomy opened for them pathway into a life where they could manage their time and intellectual potential for motives of their own. Marriage with the subsequent childbirth stopped being perceived as an inevitable life scenario [6]. Instead, it started seeming to be a hindrance in a way of career building and realization of the personal potential. Since employers expect women to prioritize family over career and quit work soon after marriage, women have to choose between family and career. In such circumstances, the percentage of marriages and births is getting lower with every year: it has been estimated that in 2017 the general marriage rate and birth rate reached the lowest point for all the time such statistics has been collected [7], [8]. As women started to feel more confident in financially supporting themselves, divorce rates also increased. The most of divorce cases are initiated by women whose unpaid domestic work has long been taken for granted by husbands and in-laws (according to the tradition, upon marriage the wife moves to the husband's family and provide service to them). In the Republic of Korea, the crude divorce rate rose from 1.05 in the early 1990 s to 2.60 in the early 2000 s (peaking at 3.4 in 2003 ) and then decreased to 2.44 in the early 2010s [8]. In Japan, the crude divorce rate also throughout the 1990s (from 1.28 in 
1990 to 2.00 in 1999), reached a peak of 2.30 in 2002 and started to decline from this point [7]. The decrease in divorce rate in the second half of the 2000s and in the 2010s should not be attributed to decline in divorce risk, rather, it reflects a decrease in the proportions of the married population [9].

Another important consequence is emergence of a generation that rejected traditional ideals and formulated new a conception of manhood and womanhood. Long-term economic stagnation has created a situation in which a generation unable to succeed in the system of values of their parents (namely lifetime employment, a secure high-paying job, nuclear family maintenance) started to create their own vision of the world and their place in it. In the post-crisis world toughness, assertiveness, positioning working duty as a priority, and other traditional attributes of hegemonic masculinity did not bring success to men and, therefore, could be rejected as unnecessary. In their turn, women were deprived of the opportunity survive as housewives, so they had to become more active and independent, to develop leadership skills.

\section{THE STRUCTURE OF GENDER IMBALANCE}

Although the situation certainly improved in the last twenty years, Japan and the Republic of Korea still rank low in gender equality [1]. According to the Report, Japan and Korea have good performance on the aspects of educational attainment and health and survival, but lack in political empowerment, economic participation and opportunity. However, it seems like equality in access to education should also be called into questioned. It was revealed by an investigation by the Yomiuri Shinbun (読売新聞) newspaper that the Tokyo Medical University was manipulating entrance exam results to exclude female applicants from competition since 2006. The reason is the long-held prejudice that women will quit work with marriage, therefore it is pointless to invest in their education [10]. Half a year later, Juntendo and Kitasato universities also admitted to lowering the passing score for men, revealing a worrying trend of discrimination against women in Japanese academic environment.

The gender imbalance is evident. The percentage of working women is $20 \%$ lower than the one of working men $(50.5 \%$ against $70.6 \%$ for Japan and $55.2 \%$ against $73.2 \%$ for Korea) [5], and women often work only part-time; the average salary for women constitutes for $70 \%$ of the one for men in Japan and $53 \%$ in Korea; women are about 5 times longer than men engaged in non-remunerated work; there is no law demanding equal pay [1]. The rate of women in top management positions is less than $10 \%$ in both countries. Professor Yamaguchi Kazuo notes that in Japan "women are deprived of the opportunity to engage in other professions other than those that are considered suitable for women" (which are professions continuing a line of traditional family roles for women, for example, teacher and nurse) [11]. This statement can also be extended to Korea. Women also suffer discrimination in hiring and career advancement and are subjected to such kinds of discrimination as, speaking in Japanese terms, matahara (マタハラ, maternity harassment, women are demoted or forced to quit because of pregnancy), sekuhara (セクハラ, sexual harassment), pawahara (パワーハラ, power harassment, abuse of power), and aruhara (アル ハラ, alcohol harassment, plying subordinates with alcohol) [12].

Women participate in "big politics" as much as it is permitted by male majority. With $13.7 \%$ and $17 \%$ of women in the Lower House of the Parliament Japan and the Republic of Korea are ranked №164 and №120 in Women in National Parliaments rating [13]. Prime Minister Abe presented a Cabinet of Ministers with a historic maximum of five women, three of whom soon quit their posts, and the only woman in the current Cabinet, regional revitalization minister Katayama Satsuki, is widely seen as being unfit for her post, as revealed by Jiji Press survey [14]. Abe's tactic of "decorating with flowers" the Cabinet while not giving women real power, the tendency for female ministers to leave their positions ahead of time, and their reducing number in the Cabinet does not inspire confidence that a powerful female figure will acquire an influential position at the highest level any time soon. Unlike Japan, Korea has already had a female head of the state (2013-2017), the first country in East Asia to do so. Nevertheless, Park Geun-hye's win cannot be called a win for gender equality movement, because to a large extent she owes her career to a male politician of her kind [15]. Voting for Park Geun-hye, Koreans hoped that she would repeat the economic miracle for which her father, former president Park Chung-hee, is famous for. In its turn, in Japan a discussion about whether a woman can become the face of the nation shows no signs of abating. According to the current law, only a man is entitled to inherit the Chrysanthemum Throne, but this may cause problems as emperor Naruhito has no sons. Before the birth of the only current heir, the emperor's nephew, only girls were born in the family, and the government was about to revise the law of succession. A great number of women in high-level government posts are getting the codicil "the first", which demonstrates the depth of the gender gap.

Not only the workplace, but home, where women spend most of their lives, is not a safe space for them. In Japan and Korea, as well as in other economically developed Asian countries, the general level of homicide is very low yet the proportion of female victims is unusually high (52.9\% in Japan and 52.9\% in Korea) [16]. Asia ranks first among the world's macroregions in the number of women killed by a partner or family members. According to a survey performed by the Korean Institute of Criminology, $80 \%$ of male respondents admitted that they showed aggressive behavior towards their girlfriends and wives [17]. This result demonstrates that the unequal power relations are rooted deeply in society, which leads to femicide and violence against women in general. Being officially prohibited, violence against women is often not perceived as something unnatural and illegal: it is widely romanticized in cinema and literature, and domestic violence is considered a family matter that is not a subject to state control.

Japan and Korea follow similar patterns of gender imbalance. There is a potential to break the pattern as the process of social transformations launched by the economic crisis formed a certain social demand for gender equality. 


\section{RESPONSE TO GENDER INEQUALITY: THE GOVERNMENT VERSUS SOCIETY}

Having reviewed the structure of gender imbalance, it is important to examine the measures taken to narrow the gap. This paper argues that while both countries have taken steps towards achieving gender equality, the incentives and results of these steps differ. In Japan the movement towards gender equality is mostly stimulated by the government and guided by economic necessity. Whereas in Korea there is a similar trend of the government supporting gender equality to a certain extent out of economic need, there is also an influential social initiative that fills in the gaps of the governmental policy. Social initiative was the core reason Korea took its most essential step towards achieving gender equality, abolishing the male-oriented family registry system, that is yet to be completed by Japan.

First of all, it is necessary to note public bodies responsible for gender equality and protecting women's rights: the Ministry of Gender Equality and Family of the Republic of Korea and the Gender Equality Bureau of Japan, which both were established in 2001 under increasing pressure from external (the United Nations, overall trend on gender equality of Western developed countries) and internal (growing feminist movement) factors. They were created with the aims of protecting victims of human trafficking, domestic and sexual violence, developing women's potential, enhancing women's status in society, and providing analysis on the topic of compliance of government policy with the goal of achieving gender equality. It is worth noting that the Korean public body has more authority than the Japanese one. The reason, we believe, lies in the fact that the Republic of Korea has had an eventful history full of intense social perturbations and has experienced a drastic shift to the Sixth Republic. Therefore, the public is accustomed to engage in civil activity and is willing to push for reforms [18]. On the contrary, Japan has had a stable political background after the Second World War, retaining the monarchy under the almost permanent governance of the ruling Liberal Democratic Party. In such conditions people tend not to be enthusiastic to bid farewell to tradition. Feminist movement is perceived as a foreign element and remains a niche phenomenon, matters of gender equality are unlikely to appear on general public's agenda.

Prime Minister Abe made "a society where women can shine" a slogan of his policy, but in reality only intends to use women's economic potential to boost Japan's stagnating economy. In the current realities of shrinking labor supply due to aging of the population and fertility decline, Japan needs an increase in the available labor force (placing additional pressure on workers seems counterproductive, given the statistics of karoshi (過労死 , death from overwork). Prime Minister Abe Shinzo considered that women's mass entry into the labor market could fill labor shortages, increasing Japan's GDP by 15\% [19], and announced the policy of womenomics (ウーマハミクス), one of the key aspects of abenomics (アベハクス, Abe’s economic policy), in 2014. The new policy implied an increase in the number of women in the labor force in general, in the positions of top managers and also establishing an incentive for women to return to work after childbirth [20]. According to the official page of the Government of Japan, womenomics is a successful policy: from 2012 to 2018 the number of women joining the workforce increased by 2.9 million, female labor force participation rate rose to $74 \%$ in 2017 , and the percentage of women in the management positions in the private sector approaches $10 \%$. However, Japan still lags behind the rest of the world in terms of gender equality: according to a report released by the International Labor Organization, the ratio of women in leadership positions was stuck at $12 \%$ in 2018 with the global average of $27.1 \%$ [21]. In 2018, lawmakers approved a bill that urges political parties to equalize the number of men and women among candidates in national and local elections, but the bill is of a recommendatory nature and does not impose sanctions, thus will do little to alter the gender imbalance. Given this data, it is highly unlikely that Japan will manage to achieve the initial womenomics' target of $30 \%$ in female representation.

The reason behind womenomics' stalling is its failure to provide the right environment for women to maximize their potential ("Women do not feel welcome", as stated by Nobuko Kobayashi [22]). Position of the initiator of the policy himself raises concern. Abe's urging of women to take a three-year maternity leave revealed a lack of understanding of the real situation of working women and support for traditional views that reinforces the perception of women as mothers before everything else [23]. This position is rooted in the ruling party's right-wing ideology and is fueled by fear of depopulation. There is a widespread concern that female emancipation will cause serious damage to demography. Framing women without children as an "unproductive" members of the society and a burden on tax-payers is a common rhetoric among LDP members such as Mori Yoshiro or Sugita Mio [24] [25]. However, Pempel and Forsey indicate that after the initial decline, the birth rate increases [26]: financially secure women who are able to rely on social support for motherhood and childhood, are more likely to give birth, including the second child, than women who are not confident in the stability of their financial situation. The long-term prejudice runs strong not only in men, but also in women: according to Women Political Leaders and Kantar Public survey released in 2018, only $28 \%$ of Japanese women "would feel comfortable with having a woman as the CEO of a major company" [21]. Considering that this is the stance of citizens of a country where womenomics has been in action for five years, we can conclude that Abe's policy is designed to exploit women's economic potential without redefining women's rope in the society on a fundamental level.

Legal measures, while undoubtedly important for creating a structural basis for gender equality, are not enough to erase gender inequality. It is necessary to deconstruct patriarchal stereotypes and form a new paradigm in the mass consciousness, and in order to achieve this, raise awareness of gender issues. This role is assumed by social movements that fill the gaps overlooked by formal authorities and stimulate the development of the gender equality movement in areas where the government does not initiate it or does not implement it in its entirety, lagging behind the society's demands. While such movement exists in both countries, in Korea it is more influential than in Japan due to the rigid structure and reliance on a wider audience. Because of that, Korean activists also have higher chances of their voices being heard and their requirements being met by the government. For instance, wide 
public outrage which was expressed in \#MeToo movement caused the government to adopt stricter punishments for sexual assaulters; petition to the Blue House signed by 230, 000 people made the government reconsider the abortion ban, which was ruled unconstitutional in early 2019. In keeping with the tradition of Korea protest movement, gender equality campaigners are active offline. Their true power, however, lies in the Internet, where anonymity and remoteness provide a safe space for advocating for gender equality. For example, the march against spycam epidemic, the biggest female protest march in Korea's recent history, which attracted 23, 000 people according to the police and 45, 000 according to the organizers[27], was organized via the site called Courage to Be Uncomfortable. Gender equality movement meets strong resistance. For men, disregard of women works as a protective response to the loss of a clearly dominant position. Despite female activists' claims that they consider the system of male domination, not men themselves, their enemy, men treat gender equality movement as a gender war infringing on men's rights [28]. On the other hand, an avant-garde of the movement is radical feminism, supporters of which believe that since nobody paid attention to feminism when it was "nice", they need to act tougher. Their harsh statements, being also much-repeated by right-wing media, created such a negative image for the whole feminist movement in the mass consciousness, that even a suspicion of belonging to the movement can put an end to a woman's career and pose a threat to her health and safety. Nevertheless, the gender equality movement keeps gaining supporters and growing in power, and now we will discuss why.

\section{THE ISSUE THAT STARTED IT ALL}

In our opinion, we should seek for the reason for the difference in Japan's and Korea's approaches to gender equality in the transformation of national identity in the post-war period, in different attitude to the common past on the part of the state and society. Due to the fact that Korea was subjected to colonization (1910-1945), after independence, the ongoing processes of national pride restoration, reflection on complex past and reappraisal of it have been set into action (in particular, claims are alleged towards Japan, which believes that the case was closed in 1965 with the signing of The Treaty on Basic Relations). In this discourse, the theme of "comfort women" (위안부 wianbu in Korean and 慰安婦 ianfu in Japanese), victims of Japanese sexual slavery during the occupation period, is strong. This is one of the few topics related to women where the government, the media and public opinion unanimously choose the position of women's rights protection (for example, one of the electoral promises of the current President Moon Jae-In was a revision of the 2015 Japanese-Korean agreement on the issue of "comfort women", which failed to satisfy Korean public). The reason is that Korea treats the issue as a nationwide problem where the accused is an external aggressor, traditional values and principles of the country are not questioned. The nationalistic approach to the "comfort women" discourse and the tendency to use the problem to spark patriotic invocation and justify hatred for Japan was highlighted by such authors as Aniko Varga [29]. In Korea, there is a springboard for the struggle of women for their rights, since the problem of women's rights is being addressed in principle, albeit in the narrow vein of the problem of comfort women.

Hence comes women's reflection on their own position in contemporary Korea. The mental opposition "Korean women are victims and Japanese men are aggressors" loses its national identity when Koreans wonder what ideology made sexual slavery possible. They draw a parallel with the current Korean reality (women were slaves literally then and are figuratively now), recognize their oppressed position, point to the persistence of injustice, demand change. A strong connection between the movement for justice for "comfort women" and the current movement for gender equality is noted by activists: Yang Jinja, who has been working for comfort women justice groups for decades, called "comfort women" "the world's first \#MeToo campaigners" [30].

On the contrary, in Japan, there is no trend on reflecting on the trauma of the past. Back in 1970, at the time of birth of the women's movement (ウーマン・リブ uman libu, women's lib), it faced a strongly adverse public reaction, the media labelled activists as "ugly hysterical women" (this stigma has survived to this day) [31]. As Japan entered the 21 st century, the trend towards the conservation of the traditional power distribution in gender relations was clearly manifested. The authorities and the media controlled by it do not allow the thought their ancestors having been wrong in their judgements. Prime Minister Abe claims that prostitution at comfort stations was voluntary, the mayor of Osaka Toru Hashimoto argues that the system of comfort stations was necessary to maintain military discipline (and, may we add, therefore is justified and cannot be considered a crime). As part of the Japanese government's trend on denying war crimes committed by Japan in World War II, these statements demonstrate the officials' attitude to women's rights. In a society where the issue of liability for crimes against women in the past is not raised, it is difficult for the social movement towards reviewing the rights and obligations of women in the present to prosper.

\section{CONCLUSION}

The processes of reshaping the current power structure and gender hierarchy currently occurring in Japan and The Republic of Korea, determine the future of these countries in social, economical, cultural, political perspectives, therefore the research on the topic is of utmost importance.

The previous research interpreted movement to gender equality as a result of structural transformations in the economy and enhanced civic engagement. However, cross national comparative studies concerning the issue are not represented sufficiently in the scholarly literature, and this paper aims to fill in the gap in the body of knowledge. The paper approaches the topic from a new position, providing a look on Japanese and South Korean socioeconomic processes through the prism of international relations.

The present research proposes that with the Asian economic crisis being the impetus for gender hierarchy revision in both countries, the difference in attitude to the "comfort women" problem is the reason for different routes the countries have taken in overcoming gender inequality. 


\section{REFERENCES}

[1] World Economic Forum (WEF). (2018). The Global Gender Gap Report. [Online]. https://www.weforum.org/reports/the-global-gender-gap-report-2018

[2] C.H. Cho. (April 2010). Abolishing the hoju system. The Korea Herald. [Online]. http://www.koreaherald.com/view.php?ud=20050323000033

[3] Yo.Sugimoto, An Introduction to Japanese Society; New York: Cambridge University Press, 2010.

[4] H.S. Kwon, "The Military Sexual Slavery Issue and Asian Peace", presented at the First East Asian Women's Forum, Japan, October 20-22, 1994

[5] United Nations Development Programme (UNDP). (2019). Table 5: Gender Inequality Index. [Online]. Available: http://hdr.undp.org/en/composite/GII

[6] J. Ryall. (June 2016). Why fewer Japanese are seeking marriage. Deutsche Welle at a glance. [Online]. Available: https://www.dw.com/en/why-fewer-japanese-are-seeking-marriage/a-19 349576

[7] National Institute of Population and Social Security Research (IPSS). (2017). Population Statistics of Japan 2017. [Online]. Available: http://www.ipss.go.jp/p-info/e/psj2017/PSJ2017.asp

[8] KOrean Statistics Information Service (KOSIS). (2019). Vital statistics of Korea. [Online].

Available: http://kosis.kr/eng/statisticsList/statisticsListIndex.do?menuId=M_01_0 $1 \&$ vwcd=MT_ETITLE\&parmTabId=M_01_01\#SelectStatsBoxDiv

[9] M. Chen, P.S.F. Yui, "Decomposing the crude divorce rate in five countries: Singapore, Taiwan, South Korea, the UK, and Australia", Asian Population Studies, vol.14, no.2, pp.137-152, 2018, April 2018. https://doi.org/10.1080/17441730.2018.1452380

[10] H.Haruno. 堀家春野. (August 2018). Tōkyō idai naze nyūshi de "josei sabetsu”(jiron kōron) 「東京医大 なぜ入試で『女性差別』」（時 論公論） [Tokyo Medical University, why are women discriminated at the entrance exams]. NHK. [Online]. Available: http://www.nhk.or.jp/kaisetsu-blog/100/303228.html

[11] K. Yamaguchi, "Gendernui razruv v Yaponii" [Gender gap in Japan], Financu i razvitie, vol. 56, no.1, pp.26-29, March 2019.

[12] K. Muta. 牟田 和恵. (April 2015). Sekuhara ni kizukanai otoko-tachi, No to ienai On'na-tachi セク八ラに気づかない男たち、Noと言えな い女たち [Men who do not notice sekuhara, women who cannot say no]. Nippon.com. [Online].

Available: https://www.nippon.com/ja/currents/d00171/

[13] Inter-Parliamentary Union. (2019). Women in national parliaments. [Online]. Available: http://archive.ipu.org/wmn-e/classif.htm

[14] Satsuki Katayama, Japan's only female minister, is most widely seen as unfit for the post, a survey finds. (December 2018). The Japan Times. [Online]. Available: https://www.japantimes.co.jp/news/2018/12/14/national/politics-diplom acy/satsuki-katayama-widely-seen-unfit-japans-cabinet-survey-finds/\#. XO5X2_ZuI2w

[15] N.N. Kim, E.Ya. Khokhlova, "Evolutsia sotsial'nogo polozeniya zenshin v Koree: ot traditsionnogo obschestva k sovremennomu" [Evolution of the social status of women in Korean society: from traditional to modern society], Oriens, no. 3. pp. 106-122, May 2017.

[16] United Nations Office on Drugs and Crime (UNODC). (2013). Global study on Homicide. [Online]. Available: https://www.unodc.org/documents/gsh/pdfs/2014_GLOBAL_HOMICID E_BOOK_web.pdf

[17] S. Maybin. (August 2018). Pokoleniie sampo: pochemu zhenshinuy v Yuzhnoi Koree ne hotyat detei i otnoshenii [Sampo generation: why women in South Korea do not want kids and relationships]. BBC Russia. [Online]. Available: https://www.bbc.com/russian/features-45209116

[18] R. Premack. (December 2016). Koreans Have Mastered the Art of the Protest. Foreign Policy. [Online]. Available: https://foreignpolicy.com/2016/12/02/koreans-have-mastered-the-art-ofthe-protest/

[19] A. Friedman. (December 2016). Boosting Japan's Workforce (and Womenomics) through Immigration. Center for Strategic and International Studies. [Online]. Available: https://www.csis.org/analysis/boosting-japans-workforce-and-womenom ics-through-immigration
[20] K. Iwata. 岩田 喜美枝. (June 2013). Abenomikusu no yō,”josei no katsuyaku" wo jitsugen suru tame ni アベノミクスの要、「女性の活 躍」を実現するために [The essence of Abenomics is "women’s activity" implementation]. Nippon.com. [Online]. Available: https://www.nippon.com/ja/currents/d00087/

[21] Ch. Tanaka. (March 2019). Six years into Abe's womenomics push, women in Japan still struggling to shine. The Japan Times. [Online]. Available:

https://www.japantimes.co.jp/news/2019/03/08/national/social-issues/si $\mathrm{x}$-years-abes-womenomics-push-women-japan-still-struggling-shine/\#.X Ol5C_ZuI2z

[22] N. Kobayashi. (January 2018). Let's get real about female equality in corporate Japan. Nikkei Asian Review. [Online]. Available: https://asia.nikkei.com/Opinion/Let-s-get-real-about-female-equality-incorporate-Japan2

[23] T. Otake. (June 2014). 'Womenomics' push raises suspicions for lack of reality. The Japan Times. [Online]. Available: https://www.japantimes.co.jp/news/2014/06/15/national/womenomics-p ush-raises-suspicions-lack-reality/\#.XO15AfZuI2z

[24] Yu. Nikaido. 二階堂友紀. (July 2018). Dōsei kappuru wa "shōsansei nashi” Sugita Mio-shi no kikō ni hihan 同性カップルは「生産性なし $」$ 杉田水脈氏の寄稿に批判 [Same-sex couples criticize Sugita Mio's article on unproductiveness]. Asahi Shimbun digital. [Online]. Available: https://www.asahi.com/articles/ASL7R4SB9L7RUTFK00L.html?iref=p c_extlink

[25] K. Hemmann. "Dangerous Women and Dangerous Stories: Gendered Narration in Kirino Natsuo's Grotesque and Real World," in Rethinking Japanese Feminisms, J. Bullock, A. Kano, J.Welker, Ed. Honolulu: University of Hawai'i Press, 2018, ch.10, pp. 170-184. https://doi.org/10.1515/9780824866730-012

[26] T.J. Pempel, J.M. Forcey, "Demography, Gender and the Problems of Japan's Economy", in Proceedings of Asia Programme Meeting Summary, pp. 1-6, London: Royal Institute of International Affairs, 2015.

[27] Hyehwayŏk siwi: Hyehwayŏk 3ch'a siwi yŏllyŏ... simin panŭngŭn ŏttŏlkka 혜화역 시위: 혜화역 3 차 시위 열려... 시민 반응은 어뗠까 [Hyehwa Station protest: the third round of protests at Hyehwa station]. (July 2018). BBS News Korea. [Online]. Available: https://www.bbc.com/korean/news-44707400\#

[28] H. Pak, M. Sin. (June 2018). "T'ewae manŭn yŏsŏngi moina?” T'e Hyehwayŏk shiwi unyŏngjinege murŏtta "왜 많은 여성이 모이나?" 혜화역 시위 운영진에 게 물었다 ["Why do so many women gather?" We asked the Hyehwa station protesters]. The Hankyore. [Online]. Available: http://www.hani.co.kr/arti/society/society_general/849982.html

[29] A. Varga, "National Bodies: The 'Comfort Women' Discourse and its Controversies in South Korea," Studies in Ethnicity and Nationalism, vol. 9, no. 2, pp. 287-303, September 2009. https://doi.org/10.1111/j.1754-9469.2009.01054.x

[30] C. Norma. (2018). The first \#MeToo activists: Contemporary campaigning in support of the former Japanese military "comfort women". [Online]. Available: https://www.academia.edu/38423715/The_first_MeToo_activists_Conte mporary_campaigning_in_support_of_the_former_Japanese_military_c omfort_women

[31] M. Ito. (October 2015). Women of Japan unite: Examining the contemporary state of feminism. The Japan Times. [Online]. Available: https://www.japantimes.co.jp/life/2015/10/03/lifestyle/women-japan-uni te-examining-contemporary-state-feminism/\#.XKDZnPZuI2w

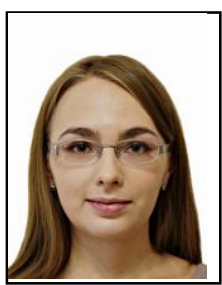

Andreeva Anastasiia was born in Arkhalgelsk, Russia, in 1998. The author is currently getting a bachelor degree in Asian and African studies in National Research University Higher School of Economics, Saint Petersburg, Russia.

She is interested in gender studies, Japanese and Korean studies, social anthropology.

Ms. Andreeva won the $1^{\text {st }}$ place in Student Research Paper Competition held by HSE in "World Economy and Global Politics, Asian Studies" subject area, and therefore was given a grant to participate in an international conference and publish an article. 